Thematic course: Solid state nanoreactor. Part IX.

\title{
Equilibrium constants of the sorption of pyridinecarboxylic acids by polystyrene type sulfocationite
}

\author{
(C) Elena V. Ostapova, ${ }^{*}$ Sergey Yu. Lyrschikov, ${ }^{+}$and Heinrich N. Altshuler \\ Federal Research Center of Coal and Coal Chemistry. Siberian Branch of Russian Academy of Sciences. \\ Sovetsky pr., 18. Kemerovo, 650000. Russia. Phone: +7 (384-2) 36-88-04.E-mail: altshulerh@gmail.com
}

Keywords: nicotinic acid, isonicotinic acid, sulfonic cation exchanger, KU-2-8, KU-2-4, ion exchange, ligand sorption, equilibrium constant.

\begin{abstract}
The processes of sorption of pyridine-3-carboxylic (nicotinic) and pyridine-4-carboxylic (isonicotinic) acids by sulfonic acid cation exchangers of the polystyrene type (CU-2-4 and CU-2-8) from aqueous solutions with different $\mathrm{pH}$ values were studied. Analysis of the FTIR spectra of isonicotinic acid, isonicotinic acid sulfate, and CU-2-8 sulfonic cation exchanger filled with isonicotinic acid showed that pyridinecarboxylic acid is in the protonated form in the polymer phase. Experimental data of the equilibrium distribution of acids in the aqueous solution-cation exchange system have been obtained. The values of the equilibrium constants for ion exchange and ligand sorption processes involving various forms of pyridinecarboxylic acid, sulfonic cation exchanger, and protons were calculated. The equilibrium constants for the ion exchange of sulfocationite protons by pyridinecarboxylic acid cations from solution are in the range 3.3-4.4. The selectivity of sulfonic cation exchangers to cations increases in the sequences proton $<$ nicotinic acid cation $<$ isonicotinic acid cation. The values of the equilibrium constant for ligand sorption of molecules are 195-220 $\mathrm{dm}^{3} / \mathrm{mol}$ for isonicotinic acid and reach $320-330 \mathrm{dm}^{3} / \mathrm{mol}$ for nicotinic acid, i.e. the sorption activity of the Hform of the cation exchanger is higher in relation to nicotinic acid molecules. A change in the amount of a crosslinking agent (from $4 \%$ to $8 \%$ divinylbenzene) in a polystyrene type sulfonic cation exchanger does not significantly affect its sorption activity towards pyridinecarboxylic acids.
\end{abstract}

\section{References}

[1] A.B. Weitberg. Effect of nicotinic acid supplementation in vivo on oxygen radical-induced genetic damage in human lymphocytes. Mutat. Res. 1989. Vol.216. P.197-201.

[2] L. Cantarellab, A. Gallifuocoa, A. Malandraa, L. Martínkovác, A. Speraa, M. Cantarellaa. High-yield continuous production of nicotinic acid via nitrile hydratase-amidase cascade reactions using cascade CSMRs. Enz. Mic. Tech. 2011. Vol.48. No.4-5. P.345-350.

[3] L.A. Carlson. Nicotinic acid: the broad-spectrum lipid drug. J. Intern. Med. 2005. Vol.258. P.94-114.

[4] M.D. Mashkovsky. Medicines. M .: New Wave. 2002. Vol.1. 14th edition. 608p. (russian)

[5] W. Wang, A. Basinger, R.A. Neese, B. Shane, S.A. Myong, M. Christiansen, M.K. Hellerstein. Effect of nicotinic acid administration on hepatic very low density lipoprotein-triglyceride production. $A m$. $J$. Physiol. Endocrinol Metab. 2001. Vol.43. P.540-547.

[6] O.A. Minyaeva, and V.I. Safonov. Some common regularities of change colligative and refractometric properties of aqueous solutions low molecular weight amino acids and water-soluble vitamins. Butlerov Communications. 2016. Vol.46. No.6. P.124-128. DOI: 10.37952/ROI-jbc-01/16-46-6-124

[7] J.H. Van Loenhout-Rooyackers, J. Veen. Treatment of pulmonary tuberculosis. Neth. J. Med. 1998. Vol.53. No.1. P.7-14.

[8] D. Boltz, X. Peng, M. Muzzio, P. Dash, P.G. Thomas, V. Margitich. Activity of enisamium, an isonicotinic acid derivative, against influenza viruses in differentiated normal human bronchial epithelial cells. Antivir. Chem. Chemother. 2018. Vol.26. DOI: 10.1177/2040206618811416

[9] E.V. Ostapova, G.Yu. Shkurenko, S.Yu. Lyrschikov, and H.N. Altshuler. Sulphonated network polymers as containers for bioactive substances Butlerov Communications. 2016. Vol.48. No.10. P.37-42. DOI: 10.37952/ROI-jbc-01/16-48-10-37 
[10] H.N. Altshuler, G.Yu. Shkurenko, N.V. Malyshenko, and S.Yu. Lyrschikov. Immobilization of pyridinecarboxylic acids in a polymer nanocontainer based on the AB-17-8 strongly basic anion exchanger Butlerov Communications. 2018. Vol.54. No.4. P.82-87. DOI: 10.37952/ROI-jbc-01/18-54-4-82

[11] H.N. Altshuler, G. Yu. Shkurenko, and S.Yu. Lyrschikov. Solid state nanoreactor. Part VIII. Encapsulation of isoquinoline in a polymer nanocontainer based on the CU-2-4 sulfocationite. Butlerov Communications. 2020. Vol.61. No.2. P.97-102. DOI: 10.37952/ROI-jbc-01/20-61-2-97

[12] H.N. Altshuler, E.V. Ostapova, O.H. Altshuler, G.Yu. Shkurenko, N.V. Malyshenko, S.Yu. Lyrshchikov, R.S. Parshkov. Encapsulation of niacin into nanocontainers on ion exchanger matrices. Russ. J. Appl. Chem. 2019. Vol.92. No.4. P.523.

[13] G.N. Altshuler, G.Y. Shkurenko, E.V. Ostapova, O.G. Altshuler. Cation exchange kinetics of pyridinecarboxylic acids. Russ. Chem. Bull. 2017. No.7. P.1177.

[14] G.N. Altshuler, E.V. Ostapova, N.V. Malyshenko, O.G. Altshuler. Sorption of nicotinic and isonicotinic acids by the strongly basic anion exchanger AB-17-8. Russ. Chem. Bull. 2017. No.10. P.1854.

[15] L.P. Abramova, O.H. Altshuler, N.V. Malyshenko, E.V. Ostapova, L.A. Sapozhnikova, G.Yu. Shkurenko, H.N. Altshuler. Obtaining of physiologically active compounds by oxidation of the individual components of coal tar in the solid-phase nanoreactors. Bulletin of the Kuzbass State Technical University. 2014. No.4. P.77-82. (russian)

[16] H.N. Altshuler. Synthesis of pyridinecarboxylic acids by the catalytic oxidation of coal tar components on metal-polymer nanocomposites. Solid Fuel Chemistry. 2012. Vol.46. No.4. P.275-278.

[17] The International Pharmacopoeia, Fifth Edition. http://apps.who.int/phint/en/p/docf

[18] M. Marhol. Ion Exchangers in Analytical Chemistry. Their Properties and Use in Inorganic Chemistry, Prague: Academia. 1982. 586p.

[19] P. Koczon, J.Cz. Dobrowolski, W. Lewandowski, A.P. Mazurekd. Experimental and theoretical IR and Raman spectra of picolinic, nicotinic and isonicotinic acids. J. Mol. Struct. 2003. Vol.655. P.89-95.

[20] Nomenclature rules of IUPAC on chemistry. Moscow: VINITI. 1979. Vol.1. half of volume 2. P.575. (russian)

[21] G.L. Gaines, Jr.Thomas H.C. Adsorption Studies on Clay Minerals. II. A Formulation of the Thermodynamics of Exchange Adsorption. J. Chem. Phys. 1953. Vol.11. No.4. P.714.

[22] A.G. Asuero, M.J. Navas, A. Herrador. Numerical evaluation of overlapping acidity constants from the ratio of absorbances at two wavelengths. Microchimica Acta. 1986. No.5-6. P.395-406. 